\title{
Social demographic aspects and self-referred health conditions of men attending a health care unit
}

\author{
Condições sociodemográficas e de saúde autorreferidas de homens em uma unidade de \\ saúde
}
Condiciones sociodemográficas y de salud auto referidas de hombres en una unidad de salud

Raissa de Oliveira Martins Cabacinha ${ }^{1}$, Christian Dias Cabacinha ${ }^{2}$, Daniel Silva Moraes ${ }^{1}$, Henrique Andrade Barbosa $^{1,3}$, Lucinéia de Pinho ${ }^{1,3}$

This study aimed at characterizing social demographic aspects and health conditions of men attending a Primary Family Health Care unit in Montes Claros, MG, Brazil, correlating these variables with health self-perception and identifying men's difficulty in using the health service. 115 adult men were interviewed who had attended the service in April and May, 2013. Most of them had completed high school, were married and adopted healthy practices, although they consumed alcoholic beverages. The main complaint regarding the health service was the long waiting time for attendance. The main factors that contributed for negative self-perception of health were: being married, suffering from chronic diseases and having low education; whereas those that contributed to the positive self-perception of health were: being young, being employed and not making regular use of medication $(\mathrm{p}<0.05)$. Those findings can subsidize policies to prevent diseases in promoting men's health.

Descriptors: Men's Health; Health Services; Gender and Health.

O objetivo deste estudo foi caracterizar as condições sociodemográficas e de saúde em homens atendidos em uma Unidade Básica de Saúde da Família de Montes Claros, MG, Brasil correlacionar essas variáveis à percepção da saúde e identificar as dificuldades dos homens no atendimento prestado pelo serviço. Entrevistou-se 115 homens adultos que buscaram a unidade de saúde entre abril e maio de 2013. A maioria tinha ensino médio completo, era casada e adotava práticas saudáveis embora consumisse álcool. A maior reclamação sobre o serviço de saúde foi a demora para o atendimento. Os fatores que mais contribuíram para autoavaliação negativa da saúde foram ter um companheiro(a), doenças crônicas e baixa escolaridade; e os mais significativos para autoavaliação positiva da saúde foram ser jovens, ter um trabalho e não fazer uso regular de medicamentos ( $\mathrm{p}<0.05)$. Os resultados podem subsidiar políticas de prevenção de doenças e promoção de saúde para população masculina.

Descritores: Saúde do Homem; Serviços de Saúde; Gênero e Saúde.

El objetivo fue caracterizar las condiciones sociodemográficas y de salud de hombres atendidos en una Unidad Básica de Salud de Montes Claros, MG, Brasil, y correlacionar estas variables con la percepción de salud e identificar las dificultades de los hombres en servicio. Se entrevistaron 115 hombres adultos que buscaban la unidad de salud, entre abril y mayo de 2013. La mayoría tenía enseñanza secundaria completa, era casada y adoptaba prácticas saludables, sin embargo consumiera alcohol. La mayor queja sobre el servicio fue el retraso para la atención. Los factores que más contribuyeron a la percepción negativa de la salud fueron tener un compañero, enfermedades crónicas y bajo nivel educativo; y los más importantes para la autopercepción positiva de salud fueron ser joven, tener un trabajo y no hace uso regular de medicamentos ( $\mathrm{p}<0,05)$. Los resultados pueden reforzar las políticas de prevención de enfermedades y promoción de salud la población masculina.

Descriptores: Salud del Hombre; Servicios de Salud; Género y Salud.

\footnotetext{
${ }^{1}$ Faculdades Santo Agostinho. Montes Claros, MG, Brazil.

${ }^{2}$ Universidade Federal de Minas Gerais. Montes Claros, MG, Brazil.

${ }^{3}$ Universidade Estadual de Montes Claros. Montes Claros, MG, Brazil.
}

Corresponding author: Lucinéia de Pinho

Av. Osmane Barbosa, 937, JK, CEP: 39404-006. Montes Claros, MG, Brazil. E-mail: lucineiapinho@hotmail.com 


\section{Introduction}

The production of researches concerning man and his health, above all the ones directed to themes such as the access and use of services, profiles of morbidity/mortality and representations on health and diseases in specific social groups ${ }^{(1-5)}$. Studies report that men, in general, suffer more of severe and chronic conditions of health than women, and also have a higher rate of death due to those diseases ${ }^{(2)}$. Statistics show that from each three deaths of adult people, two are men. They live, in average, seven years less than the women, and among the main chronic diseases they present are cardiopathy, cancer, diabetes, hypercholesterolemia and arterial hypertension ${ }^{(6)}$. Despite the high rate of morbidity/mortality among men, they go to the services of primary attention to health less often than the women ${ }^{(1,2)}$.

Many are the suppositions and justifications for the low attendance of men to the health services, and their inclusion in actions of such nature is a challenge, once they commonly do not recognize the importance of the care and the valuing of a healthy body as male social issues ${ }^{(1,7)}$. The matters concerning work, difficulty of access to the services, lack of units, which are specifically turned to the health of men and representation of the care as a female task, are the main reasons expressed by the subjects for the low attendance to the services of health ${ }^{(2)}$.

In Brazil, the National Policy of Integral Health Care of Men guides the elaboration of strategies and actions for the promotion of health and the prevention of diseases based on integral care. However, there are faults in the health system which jeopardize the compliance with the policy for the promotion of men's health, which range from the adequate issue of structure of assistance in basic attention to the motivation and development of actions of promotion against the most frequent diseases in this population ${ }^{(8)}$.

Besides the discussion on men's health, it is important to know whether the male representation on this theme is the same in different social groups, once the matters of work, access to health services and conception of masculinity differ among those groups. Such knowledge can subsidize the nursing professional in more specific educative actions of health promotion and prevention of diseases ${ }^{(9-10)}$.

In this context, this study has as objective to characterize the health and social demographic conditions in a group of men assisted in a Basic Family Health Unit, correlating social demographic variables to the perception of health and identifying their difficulties concerning the assistance in the health services.

\section{Method}

It is a cross-sectional quantitative research, investigating the adult male population assisted at a basic health unit of Montes Claros, MG, Brazil, in April and May, 2013. The county has 361,915 inhabitants, of which 174,249 (48.15\%) are male and 100,147 $(54.47 \%)$ are between 20 and 59 years of age. The study was developed at a health unit which has been providing assistance to the community since 1983, assisting approximately 400 male subjects per year.

The size of the sample was defined based on the number of men assisted by the health unit per year and considering $95 \%$ of interval of confidence, $10 \%$ of sample error and $15 \%$ for possible losses. A minimum sample of 86 men was established; however the final sample consisted of 115 men.

The criteria of inclusion were: being older than 18, being registered at the health unit and show interest and time availability to answer the questionnaire. Participants who did not answer the whole questionnaire were excluded.

During the data collection, the men who searched for the service came in different shifts (morning, afternoon and evening) and were approached at random and invited to participate in the study. The ones who accepted were interviewed based on a reference questionnaire in the reading ${ }^{(11)}$ and adapted for the study. It is divided in three 
sections: social demographic characterization (sex, age, schooling, income and source of income); risk factors and protection factors (tobacco smoking, practice of physical activities, diet and alcoholism) and conditions of health and assistance (assistance at a reference health service, doctor's appointment, regular use of medication, chronical diseases and selfreferred health condition) ${ }^{(11)}$. The self-referred heath condition was reported into four categories: excellent, good, regular or bad.

Through the distribution of frequencies, the descriptive analysis of the social demographic variables of style of life and the ones concerning health was made. Fisher's exact test was used, with level of significance of $5 \%$, to evaluate the association between the situation of self-referred health and the other variables. For the analysis, the category of selfreferred health was transformed into a dichotomy variable (excellent/good and regular/bad). The tests were made with the Software Statistical Package for Social Sciences 19.0 program.

The study was made complying with the precepts, established in Resolution no. 466/12 of the Health National Counsel on researches with human beings, and was approved by the Committee of Ethics in Research (Protocol of approval no. 266,717).

\section{Results}

The 115 men interviewed were between 18 and 81 years of age (average $=42.10$; standard deviation=17.43). The largest part of the population of the study had a partner (55.6\%), at least grade school (62.6\%), owned their homes $(62.6 \%)$ and were part of the category of paid workers in activity (67.8\%) (Table 1).
Table 1 - Social demographic characterization of men of the users of a health unit $(n=115)$

\begin{tabular}{lc}
\hline Variables & $\mathbf{n}(\mathbf{\%})$ \\
\hline Age range (years) & \\
$\leq 30$ & $44(38.3)$ \\
31 - 40 & $12(10.4)$ \\
$41-50$ & $22(19.1)$ \\
51 - 60 & $17(14.8)$ \\
$\geq 61$ & $20(17.4)$ \\
Schooling & \\
Illiterate & $7(6.1)$ \\
Grade School & $42(36.5)$ \\
High School & $45(39.1)$ \\
University & $21(18.3)$ \\
Marital status & \\
With partner & $64(55.7)$ \\
Without partner & $51(44.3)$ \\
Housing & \\
Own & $72(62.6)$ \\
Rented & $26(22.6)$ \\
Courtesy & $17(14.8)$ \\
Formal work & \\
Yes & $78(67.8)$ \\
No & $37(32.2)$ \\
\hline
\end{tabular}

In general the interviewees reported having healthy habits (Table 2). The daily consumption of fruits and vegetables was reported by $57.4 \%(n=66)$ of men. A proportion of $67.8 \%(n=78)$ of the participants never smoked and $72 \%(\mathrm{n}=83)$ practiced physical activities. However, most of men reported to consume alcoholic beverages (50.4\%).

Table 2 - Style of life of men, users of a Health Unit $(\mathrm{n}=115)$

\begin{tabular}{lc}
\hline Variables & n \% \\
\hline Consumption of fruits and vegetables & \\
$\quad$ Daily & $66(57.4)$ \\
$1 \mathrm{x}$ to 3x/ week & $43(37.4)$ \\
None & $6(5.2)$ \\
Smoking habits & \\
$\quad$ Smoker & $8(7.0)$ \\
Former smoker & $29(25.2)$ \\
$\quad$ Non smoker & $78(67.8)$ \\
Consumption of alcoholic beverages & \\
Yes & $58(50.4)$ \\
No & $57(49.6)$ \\
Physical Activities Practices & \\
Yes & $83(72.2)$ \\
No & $32(27.8)$ \\
\hline
\end{tabular}


In Table 3, it is observed that $77.4 \%(n=89)$ of the interviewed men classified their health as good or excellent. Most of the interviewees reported not to have any diseases, and among those who reported to have some kind of diseases, the main ones were: arterial hypertension, hypercholesterolemia, hypertriglyceridemia and hyperglycemia, which can be considered some of the main risk factors for cardiovascular alterations.

Regarding the average of the frequency concerning the medical appointments by the interviewees in the last year, it is noticed that $63.5 \%$ attended at least one appointment, but 73\% did not attend specialist doctors' appointments frequently. More than half of the men studied did not take medication regularly (67.8\%) and 93.9\% were not hospitalized in the last year.

Table 3 shows variables which characterize the use of health services. The Unified Health Service is the main health service used by $66.1 \%$ of men, who, in general, reported not having any difficulty to attend it. But when questioned on the problems faced when they looked for the health services, the main factor reported was the delay in the assistance.

The relation between the condition of health and the variables studied is shown in Table 4. In this study the following social demographic variables: age range, schooling, marital status and work as well as the variables of health chronical conditions and the regular use of medication presented significant association with regular/bad self-referred health $(\mathrm{p}<0,05)$ (Table 4).
Table 3 - Health conditions and standard of use of health services of men users of a Health Unit

\begin{tabular}{|c|c|}
\hline Variables & n \% \\
\hline \multicolumn{2}{|l|}{ Self-perception of health } \\
\hline Excellent & $35(30.4)$ \\
\hline Good & $54(47.0)$ \\
\hline Regular & $24(20.9)$ \\
\hline Bad & $2(1.7)$ \\
\hline \multicolumn{2}{|c|}{ Number of self-referred chronic conditions ${ }^{(a)}$} \\
\hline None & $65(56.4)$ \\
\hline 1 & $21(18.3)$ \\
\hline 2 & $21(18.3)$ \\
\hline 3 or more & $8(7.0)$ \\
\hline \multicolumn{2}{|c|}{ Frequency of medical appointment } \\
\hline Weekly & $5(4.3)$ \\
\hline $4 \mathrm{x}$ a $12 \mathrm{x} /$ year & $27(23.5)$ \\
\hline $1 \mathrm{x}$ a $3 \mathrm{x} /$ year & $41(35.7)$ \\
\hline Never & $42(36.5)$ \\
\hline \multicolumn{2}{|c|}{$\begin{array}{l}\text { Do you attend specialist doctor's appointment } \\
\text { frequently? }{ }^{(\mathrm{b})}\end{array}$} \\
\hline Yes & $31(27.0)$ \\
\hline No & $84(73.0)$ \\
\hline \multicolumn{2}{|l|}{ Use of regular medication } \\
\hline Yes & $37(32.2)$ \\
\hline No & $78(67.8)$ \\
\hline \multicolumn{2}{|c|}{ Hospitalization in the last 12 months } \\
\hline Yes & $7(6.1)$ \\
\hline No & $108(93.9)$ \\
\hline \multicolumn{2}{|c|}{ What is difficult to attend the routine health service? } \\
\hline Nothing & $58(50.4)$ \\
\hline Bad assistance & $26(22.6)$ \\
\hline Difficulty of access & $13(11.3)$ \\
\hline Lack of time & $18(15.7)$ \\
\hline \multicolumn{2}{|c|}{ Health service used in the last appointment } \\
\hline Unified Health System & $76(66.1)$ \\
\hline Private health plan & $32(27.8)$ \\
\hline Private & $7(6.1)$ \\
\hline \multicolumn{2}{|c|}{$\begin{array}{l}\text { Problems faced in the health services in the last } \\
\text { appointment }\end{array}$} \\
\hline Delay in the assistance & $83(72.2)$ \\
\hline Delay in the exams & $14(12.2)$ \\
\hline Lack of staff and material ${ }^{(c)}$ & $10(8.6)$ \\
\hline Bad assistance & $8(7.0)$ \\
\hline
\end{tabular}


Table 4 - Bivariate analysis of the social demographic characteristics, of life style and of health of male users at a health unit

\begin{tabular}{|c|c|c|c|}
\hline Variables & $\begin{array}{c}\text { Regular/ } \\
\text { bad }\end{array}$ & $\begin{array}{c}\text { Excellent/ } \\
\text { good }\end{array}$ & $\begin{array}{c}\text { Value } \\
\text { of } p \\
\end{array}$ \\
\hline \multicolumn{4}{|l|}{ Age range (years) } \\
\hline 18 to 40 & 4 & 52 & \multirow{2}{*}{0.000} \\
\hline 41 or more & 22 & 37 & \\
\hline \multicolumn{4}{|l|}{ Schooling (years) } \\
\hline 0 to 8 & 8 & 58 & \multirow{2}{*}{0.003} \\
\hline 9 or more & 18 & 31 & \\
\hline \multicolumn{4}{|l|}{ Marital status } \\
\hline With partner & 21 & 43 & \multirow{2}{*}{0.004} \\
\hline Without partner & 5 & 46 & \\
\hline \multicolumn{4}{|l|}{ Working } \\
\hline Yes & 11 & 73 & \multirow{2}{*}{0.017} \\
\hline No & 15 & 16 & \\
\hline \multicolumn{4}{|l|}{ Alcoholic beverage } \\
\hline No & 16 & 42 & \multirow{2}{*}{0.265} \\
\hline Yes & 10 & 47 & \\
\hline \multicolumn{4}{|c|}{ Chronic conditions of health } \\
\hline No & 10 & 55 & \multirow{2}{*}{0.044} \\
\hline Yes & 16 & 34 & \\
\hline \multicolumn{4}{|c|}{ Appointment with a specialist } \\
\hline No & 17 & 67 & \multirow{2}{*}{0.325} \\
\hline Yes & 9 & 22 & \\
\hline \multicolumn{4}{|c|}{ Continuous use of medication } \\
\hline No & 11 & 67 & \multirow{2}{*}{0.003} \\
\hline Yes & 15 & 22 & \\
\hline \multicolumn{4}{|c|}{ Health service of routine } \\
\hline Public & 21 & 55 & \multirow{2}{*}{0.099} \\
\hline Private & 5 & 34 & \\
\hline
\end{tabular}

\section{Discussion}

Due to cultural matters, it is common for men not to feel the need to look for medical care in order to prevent and treat diseases ${ }^{(2,10)}$. So, the inclusion of this gender in the assistance of services of primary care to health is a big challenge ${ }^{(2)}$. However, the present study shows a change of posture of that population. It was observed that the larger percentage of men attending this health service was middle-aged, with a good social economic situation and who in general perceived their health as adequate. The factors which most influenced in the distinction of health between good/excellent or regular/bad were, according to the multivariate analyses, the age range, schooling, marital status, having a job, having chronical diseases and making frequent use of medication.
The men who were investigated reported to adopt health habits in their daily activities, especially concerning the consumption of fruit and vegetables and the practice of physical activities. Prior investigations showed that changes in the style of life, with the adoption of healthy habits of life and the reduction of behaviors of risk, can reduce the incidence of diseases and guarantee good conditions of health $^{(12-13)}$.

On the other hand, it is still a challenge for the male population to control the use of alcohol, which happens by approximately half of the participants. A study on the consumption and dependence of alcohol by the adult population in the State of São Paulo, Brazil, showed that $52.9 \%$ of the men of the sample consumed alcohol abusively (ingestion of $30 \mathrm{~g}$ or more per day $)^{(14)}$. The abuse consumption of alcohol is currently characterized as one of the big problems of public health, being associated to deleterious effects on the health of the subject, his relations and social position $^{(14)}$.

Anyway, the data obtained in the present study are insufficient for the evaluation of the adequacy of the practice of physical exercises and even on the excessive consumption of alcohol. In order to have an adequate investigation of those factors, it would be necessary to have the use of a specific tool, sensitive to the determination of the quantity and frequency of the correspondent activities.

Among the problems faced in search of health services, the men interviewed reported, above all, the delay in the assistance. The slowness in the assistance was also shown as one of the main reasons why men do not look for health services according to the report of the health department which deals with the National Policy of Integral Attention to man's health ${ }^{(6)}$. For the users of the family health strategies, this fact is considered one of the negative points of the institutions of low complexity ${ }^{(15)}$.

Most of the men evaluated perceived their health as adequate. One of the factors to explain such positive self-evaluation is the age range, once 
$48.7 \%$ of the interviewed subjects were young, under 40 years of age. The self-evaluation of the health is actually more positive in adults than in young subjects $^{(12)}$. An interesting fact is that, despite the satisfactory sensation of health, the younger men were also the main users of the health services. In a study made in southern, Brazil, the authors suggest that the most frequent pursuit for health services by young adults can be due to the prevalence of chronical diseases which require the continuous assistance of the services of primary health care ${ }^{(16)}$. However, this is unlikely in the current study where both the low frequency of chronical diseases as well as the young age, were associated to the good perception of health. There is the possibility that the younger population is more aware of their health condition, although the reasons which lead to that care, have not been investigated in the present study.

Another factor which must have positively contributed for the self-evaluation of health was the fact that $56.4 \%$ of the men evaluated did not present any self-referred chronical diseases and 67.8\% did not use medication regularly. In the other men, the prevalence of arterial hypertension, hypercholesterolemia, hypertriglyceridemia and hyperglycemia were reported as the main chronic diseases, which is according to the results of other researches ${ }^{(16)}$. In this context the primary care unit is referred to as a venue of excellency for the promotion of health and prevention of diseases of men, and one of its main roles is to inform this public the main risk factors for the diseases for the gender ${ }^{(17)}$.

Two factors which negatively affected the selfperception of health were low schooling and lack of work. Other studies have also shown that illiterate subjects and with a low income have a higher chance to self-evaluate as having bad health as compared to subjects with university level of education and high income ${ }^{(12)}$. Therefore, these factors are important social economic indicators of the perception of health ${ }^{(18)}$.

One last factor which contributed for the low self-perception of health was the existence of a partner, which diverges from other studies ${ }^{(12)}$. However, as shown in a study made in Spain, the fact of being married, or living together with a partner are not conditions necessarily linked to better levels of health $^{(19)}$. In this work the authors ponder that most of the studies making an association between the marital status and the perception of health are crosssectional, which can favor the occurrence of reverse causality in this association ${ }^{(19)}$. They also suggest that in the analysis of the association between family and health characteristics, one must consider, besides the marital status, the status of the partner as well as the role of gender, social class and social cultural context $^{(19)}$. Therefore, for a deeper investigation on this subject, it would be necessary to explain the result found in the present study.

The identification of the characteristics of the population which are associated to the selfperception of health can contribute to draw a profile of the individuals who are more likely to search for health services. Confirming previous studies, the self-referred health condition can be associated to social demographic factors which lead to social inequality, as well as to comorbidities provoked by chronical diseases. These findings are important to indicate factors which must be used in the planning of strategies of promoting healthy habits and controlling chronical diseases in the male population ${ }^{(18)}$.

\section{Conclusion}

This research highlighted, that among the men evaluated, most of them who searched for health services were young (under 40 years of age) and reported good health, thus indicating the male concern with their health.

In general, the men who were users of the health public services had complete high school and favorable social economic conditions. Most men had a partner and adopted healthy practices, although they consumed alcoholic beverages. Besides that, they 
self-referred good conditions of health and the main problem concerning health assistance was the delay.

The factors which mostly contributed for a negative self-evaluation of health were having a partner, having chronical diseases and low schooling. On the other hand, the most significant factors for a positive self-evaluation of health were being young, having a job and not using medications regularly.

The results of the study can be used to subsidize policies of prevention of diseases and to promote those policies for the male population.

\section{Collaborations}

Cabacinha ROM and Moraes DS contributed for the conception of the work, data collection, analysis and interpretation of data and writing of the article. Barbosa HA and Cabacinha CD contributed for the writing of the article. Pinho L contributed in the orientation of the research, writing of the article and final approval of the version to be published.

\section{References}

1. Couto MT, Pinheiro TF, Valença O, Machin R, Silva GSN, Gomes R, et al. O homem na atenção primária à saúde: discutindo (in)visibilidade a partir da perspectiva de gênero. Interface Comun Saúde Educ. 2010; 14(33):257-70.

2. Gomes R, Moreira MCN, Nascimento EF, Rebello LEFS, Couto MT, Schraiber LB. Os homens não vêm! Ausência e/ou invisibilidade masculina na atenção primária. Ciênc Saúde Coletiva. 2011; 16(supl. 1):983-92.

3. Luizaga CTM, Gotlieb SLD. Mortalidade masculina em três capitais brasileiras, 1979 a 2007. Rev Bras Epidemiol. 2013; 16(1):87-99.

4. Machin R, Couto MT, Silva GSN, Schraiber LB, Gomes R, Figueiredo WS, et al. Concepções de gênero, masculinidade e cuidados em saúde: estudo com profissionais de saúde da atenção primária. Ciênc Saúde Coletiva. 2011; 16(11):4503-12.
5. Schraiber LB, Figueiredo WS, Gomes R, Couto MT, Pinheiro TF, Machin R, et al. Necessidades de saúde e masculinidades: atenção primária no cuidado aos homens. Cad Saúde Pública. 2010; 26(5):961-70.

6. Ministério da Saúde (BR). Política Nacional de Atenção Integral à Saúde do Homem: princípios e diretrizes. Brasília: Ministério da Saúde; 2009.

7. Knauth DR, Couto MT, Figueiredo WS. A visão dos profissionais sobre a presença e as demandas dos homens nos serviços de saúde: perspectivas para a análise da implantação da Política Nacional de Atenção Integral à Saúde do Homem. Ciênc Saúde Coletiva. 2012; 17(10):2617-26.

8. Moura EC, Santos W, Neves ACM, Gomes R, Schwarz E. Atenção a saúde dos homens no âmbito da Estratégia Saúde da Família. Ciên Saúde Coletiva. 2014; 19(2):429-38.

9. Castro CO, Tocantins FR. Necessidades assistenciais do homem na perspectiva da enfermagem e a saúde da família. Rev Pesq Cuid Fundam. 2010; 2(Supl.):813-6.

10. Silva PAS, Furtado MS, Guilhon AB, Souza NVDO, David HMSL. A saúde do homem na visão dos enfermeiros de uma unidade básica de saúde. Esc Anna Nery. 2012; 16(3):561-8.

11. Santiago LM, Novaes CO, Mattos IE. Factors associated with self-rated health among older men in a medium-sized city in Brazil. J Men's Health. 2010; 7(1):55-63.

12. Pavão ALB, Werneck GL, Campos MR. Autoavaliação do estado de saúde e a associação com fatores sociodemográficos, hábitos de vida e morbidade na população: um inquérito nacional. Cad Saúde Pública. 2013; 29(4):723-34.

13. Lachat C, Otchere S, Roberfroid D, Abdulai A, Seret FM, Milesevic J, et al. Diet and physical activity for the prevention of noncommunicable diseases in low- and middle-income countries: a systematic policy review. PLoS Med [Internet]. 2013 [cited 2014 Jul 14]:10(6). Available from: http://www.plosmedicine.org/article/info\%3Adoi\%2F10.1371\%2Fjournal.pmed.1001465 
14. Guimarães VV, Florindo AA, Stopa SR, César CLG, Barros MBA, Carandina L, et al. Consumo abusivo e dependência de álcool em população adulta no estado de São Paulo, Brasil. Rev Bras Epidemiol. $2010 ; 13(2): 314-25$.

15. Brito RS, Santos DLA, Maciel PSO. Olhar masculino acerca do atendimento na Estratégia Saúde da Família. Rev Rene. 2010; 11(4):135-42.

16. Vieira KLD, Gomes VLO, Borba MR, Costa CFS. Atendimento da população masculina em unidade básica saúde da família: motivos para a (não) procura. Esc Anna Nery. 2013; 17(1):120-7.
17. Santana EN, Lima EMM, Bulhões JLF, Monteiro EMLM, Aquino JM. A atenção à saúde do homem: ações e perspectivas dos enfermeiros. Rev Min Enferm. 2011; 15(3):324-32.

18. Barros MBA, Zanchetta LM, Moura EC, Malta DC. Auto-avaliação da saúde e fatores associados, Brasil, 2006. Rev Saúde Pública. 2009; 43(supl. 2):27-37.

19. Artazcoz L, Cortès I, Borrell C, Escribà-Agüir V, Cascant L. Social inequalities in the association between partner/marital status and health among workers in Spain. Soc Sci Med. 2011; 72(4):600-7. 